\title{
The Neotropical Amanita crebresulcata Bas: new citation from Northeast Brazil
}

\author{
Felipe Wartchow ${ }^{1,2}$ and Leonor Costa Maia ${ }^{1}$
}

Received: 04.05.2006; accepted: 08.02.2007

\begin{abstract}
The Neotropical Amanita crebresulcata Bas: new citation from Northeast Brazil). Amanita crebresulcata Bas, a species originally described from the State of Amazonas is reported for the second time out of the Amazon Forest and for the first time in northeast Brazil. Description, discussion and drawings of the species are provided.

Key words: Amanitaceae, Atlantic Forest, Vaginatae
\end{abstract}

RESUMO - (A espécie neotropical Amanita crebresulcata Bas: nova citação para o nordeste brasileiro). Amanita crebresulcata Bas, uma espécie originalmente descrita para o Estado do Amazonas, é referida pela segunda vez fora da Floresta Amazônica e pela primeira vez para o nordeste brasileiro. São apresentadas descrição, discussão e ilustração da espécie.

Palavras-chave: Amanitaceae, Mata Atlântica, Vaginatae

\section{Introduction}

Amanita Pers. is a widespread, monophyletic mushroom genus belonging to Amanitaceae R. Heim ex Pouzar (Weiß et al. 1998, Drehmel et al. 1999, Moncalvo et al. 2000), characterized by the spores being pallid-colored in mass, bilateral lamellae trama and longitudinally acrophysalidic stipe tissue, which comprises clavate terminal (and occasionally subterminal) cells longitudinally oriented on a diffuse system of usually narrow, branching hyphae (Bas 1969). In addition, it is also characterized by the socalled "schizohymenial development" (Bas 1969, Yang \& Oberwinkler 1999).

Knowledge of this genus in the tropical region of Brazil is poor; only seven species were described from the State of Amazonas by Bas (1978): A. campinaranae Bas, A. coacta Bas, A. craseoderma Bas, A. crebresulcata Bas, A. lanivolva Bas, A. sulcatissima Bas and A. xerocybe Bas. A few other species are also currently known in association with exotic pine forest [A. muscaria (L.: Fr.) Lam., A. pantherina (DC.: Fr.) Krombh. var. velatipes (Peck) Dav.J. Jenkins and A. rubescens Pers.: Fr.] (Homrich 1965, Giachini et al. 2000, Sobestiansky 2005), and
Araucaria forest or in mixed and ombrophilous forest of the State of Paraná, south Brazil: A. chrysoleuca Pegler and A. grallipes Bas \& Meijer (Bas \& Meijer 1993, Meijer 2006). Recently A. lilloi Singer was found in a public lawn in the State of Pernambuco, Northeast Brazil (Wartchow et al. 2007).

This paper presents this typical Neotropical species reported for the second time outside the Amazon region, in an Atlantic Forest of Northeast Brazil.

\section{Material and methods}

Basidiomata were collected in forest fragments located at "Usina São José" (750'20"S and $35^{\circ} 00$ ' 10 '” W), Municipality of Igarassu, Pernambuco State. The area comprises approximately 24,000 ha, of which 8,000 ha are forest fragments in different conservation stages. Average annual precipitation is up to $2,000 \mathrm{~mm}$ and average annual temperature may be as high as $27^{\circ} \mathrm{C}$ (Sectma 2001).

The methodology of this study followed Tulloss et al. (1992) and Tulloss (1993) with a modification. At the beginning of a set of spore data, the notation " $[a / b / c]$ ", where $a, b$ and $c$ are related, is to be read

1. Universidade Federal de Pernambuco, Centro de Ciências Biológicas, Departamento de Micologia, Av. Prof. Nelson Chaves s.n., 50670-901 Recife, PE, Brazil

2. Corresponding author: fwartchow@yahoo.com.br 
" $a$ spores were measured from $b$ basidiomata taken from $c$ collections." When ranges are provided in spore data in the form " $(m-) n-o(-p)$ ", the values given are to be understood as follows: $m$ is the smallest value observed or calculated, $p$ is the largest value observed or calculated. In the range of values observed or calculated, the $5^{\text {th }}$ percentile is $n$ and the $95^{\text {th }}$ percentile is $o$. A summary of definitions of biometric variables follows:

$\mathrm{w}_{\mathrm{cs}}=$ breadth of central stratum of lamella

$\mathrm{w}_{\mathrm{st}}{ }^{-}$near $=$distance from one side of central stratum to nearest base of basidium

$\mathrm{w}_{\mathrm{st}^{-}}$far $=$distance from one side of central stratum to most distant base of basidium on the same side of the central stratum

$\mathrm{L}(\mathrm{W})=$ average length (width) for spores on a specimen by specimen basis

$\mathrm{Q}=$ the ratio of length to width of a spore or the range of such ratios for all spores measured

Q' = the average of all Q values computed for all spores measured

Color names presented are based on Maerz \& Paul (1950), and for the identification of the species Bas (1978) was consulted.

\section{Result and Discussion}

Amanita crebresulcata Bas, Persoonia 10: 18. 1978. Figures 1-4

Pileus 60-70 mm, plane-depressed to planeconcave, with broad densely sulcate-striate margin; dark grayish brown MP16A3 (Phantom) at centre, somewhat slightly paler in sulcate zone; surface glabrous, viscid, shiny (mainly at centre) in dried specimen, lacking volval remnants. Lamellae free, white, membranous, crowded, with concolorous edge, approx. $5 \mathrm{~mm}$ broad, lamellulae rare. Stipe 120-125 × 7-9 mm, cylindrical, not distinctly bulbous, pale cream MP10B1 (Oyster White) with small brownish fibrils on upper half of stipe's surface, exannulate. Volva saccate, cream, membranous, thin, approx. $10 \mathrm{~mm}$ high, in dried specimens bearing narrow, fringed internal limb ("volva bitangent", see Bas 1978: 19, fig. 31). Smell and taste not recorded. Basidiospores [40/2/1] (7.5-)8-10.5(-11.5) × 7-9(-9.5) $\mu \mathrm{m}$ $(\mathrm{L}=9.1 \mu \mathrm{m} ; \mathrm{W}=8.2 \mu \mathrm{m} ; \mathrm{Q}=(1.06-) 1.10-1.26(-1.33)$; $\left.Q^{\prime}=1.20\right)$, subglobose to broadly ellipsoid, thin-walled, smooth, apiculus sublateral, with large guttule, inamyloid, hyaline, colorless. Basidia 25-30 × 10-11 $\mu \mathrm{m}$, clavate, bearing four sterigmata, each $5(-8) \mu \mathrm{m}$ high; clampless. Subhymenium cellular, with 3-4 layers of isodiametric elements 13.5-15 $\mu \mathrm{m}$ diam.; $\mathrm{w}_{\mathrm{st}}-$ near $=32-37 \mu \mathrm{m} ; \mathrm{w}_{\mathrm{st}}$-far $=35-45 \mu \mathrm{m}$. Lamella trama bilateral, with $\mathrm{w}_{\mathrm{cs}}=27-34 \mu \mathrm{m}$; divergent terminal inflated elements not seen or very rare; undifferentiated hyphae 2.5-5 $\mu \mathrm{m}$ wide, branched; vascular hyphae 4.2-5.4 $\mu \mathrm{m}$ wide, rarely branched. Pileus context acrophysalidic; acrophysalides 84-99 × 23-33 $\mu \mathrm{m}$; undifferentiated hyphae 2.5-12 $\mu \mathrm{m}$ wide; vascular hyphae up to $20 \mu \mathrm{m}$ wide, not frequent. Stipe context longitudinally acrophysalidic, with acrophysalides up to 300-370 × $75 \mu \mathrm{m}$, hyaline; undifferentiated hyphae 2-5 $\mu \mathrm{m}$ wide; vascular hyphae 5-15 $\mu \mathrm{m}$ wide, frequent. Pileipellis with subpellis as cutis approx. $180 \mu \mathrm{m}$ thick at centre of pileus; some few conspicuous subradial elements 15-20 $\mu$ m wide, with dark brown vacuolar pigment; suprapellis as ixocutis, difficult to observe, apparently ranging up to $15 \mu \mathrm{m}$ at centre; vascular hyphae $2.5-17 \mu \mathrm{m}$ wide, not branching; surface strongly gelatinous. Universal veil tissue difficult to rehydrate; undifferentiated hyphae loosely interwoven; inflated cells approx. $63 \times 45 \mu \mathrm{m}$ (e.g.), ovoid, colorless.

Habitat: isolated on soil in tropical rain forest.

Material examined: BRAZIL. Pernambuco: Igarassu, Usina São José (Mata dos Macacos), 29-VII-2005, F. Wartchow 27/2005 (URM).

Additional material examined: BRAZIL. AmAzonAs: Manaus, near INPA, 9-V-1977, R. Singer B 9680 (holotype INPA).

The broadly ellipsoid, inamyloid basidiospores, very densely sulcate margin of the pileus, and the absence of a typical bulb at the stipe base, place Amanita crebresulcata in Amanita [subgenus Amanita] section Vaginatae (Fr.) Quél. (Bas 1978). However, our collection of $A$. crebresulcata shows a discrepancy with the original diagnosis of the type from the State of Amazonas: in the type specimen, Bas (1978) described the pileipellis with a $100 \mu \mathrm{m}$ thick cutis as a subpellis and suprapellis in the form of an ixocutis. The combined elements ranged up to $125 \mu \mathrm{m}$ thick at the centre of the pileus. In contrast, the recent collection presents a pileipellis difficult to differentiate into sub and suprapellis, apparently comprising solely a cutis up to $180 \mu \mathrm{m}$ thick at the centre of the pileus. The degree of variation in the character in question is not known. Age of the basidioma, recent rain, humidity, and other factors are very likely to effect both, the 


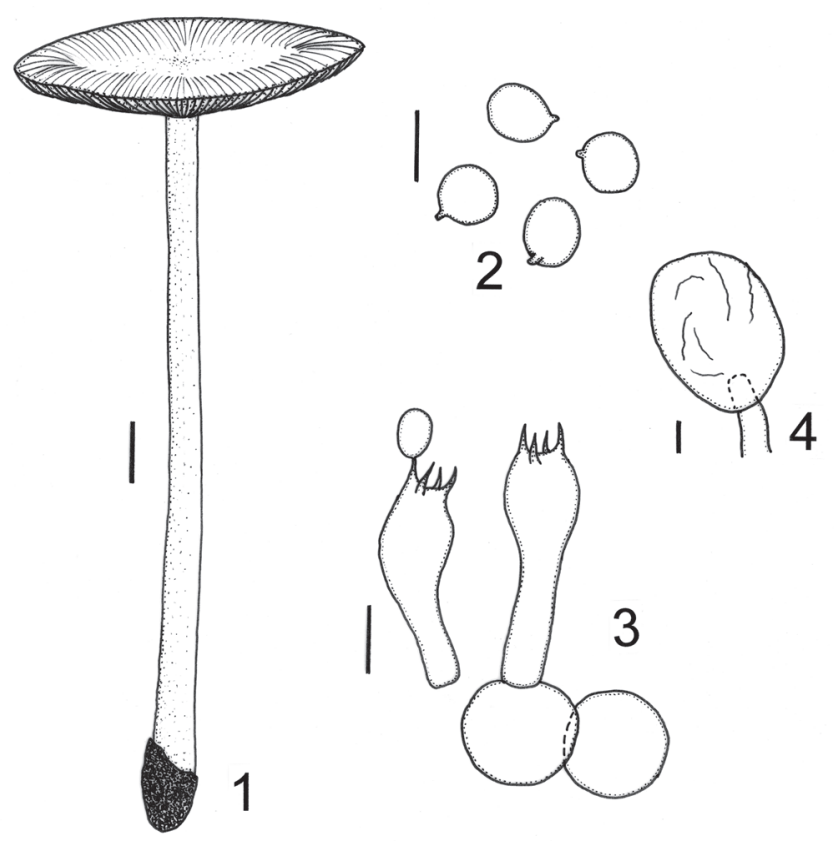

Figure 1-4. Amanita crebresulcata. 1. Habit. 2. Basidiospores. 3. Basidia and subhymenium. 4. Element of the universal veil. Scale bars: $1=10 \mathrm{~mm} ; 2-4=10 \mu \mathrm{m}$.

thickness of the subpellis, because more and more of it is gelatinized in the appropriate conditions, and the suprapellis, because as it is built up from below by gelatinization of the subpellis, and it is being lost above due to effects of the environment, including rain and desiccation (Tulloss, personal correspondence). On the other hand, the examination of the type showed that size and shape of the spores are similar to our specimen, although only a few undamaged basidiospores had been measured from a poor preserved exsiccatum: [15/1/1] (7.5-)8-10 $\times$ (6.5-)7-8.5 $\mu \mathrm{m},(\mathrm{L}=8.9 \mu \mathrm{m} ; \mathrm{W}=7.6 \mu \mathrm{m}$; $\mathrm{Q}=1.11-1.25$ (-1.3); Q' = 1.17).

This clampless species differs from $A$. coacta in sect. Vaginatae mainly by having broader ellipsoid basidiospores (Bas 1978). The third species described in this section from the State of Amazonas, A. craseoderma, also has a gelatinized pileipellis, but there are some distinguishing features: the presence of evanescent dark brown warts on the pileus, the friable volva forming a belt at the stipe base and the (sub)globose spores (Bas 1978). The other clampless Neotropical species, A. antillana Dennis from Trinidad, Martinique and Guadeloupe (Dennis 1952, Pegler 1983), has larger basidiospores, 9.8-13.3 $\times$ 7.7-10.5 $\mu \mathrm{m}$, and a friable volva (Tulloss 1994).
Amanita crebresulcata was known previously only from the State of Amazonas, growing near to several tree families, with a case of mycorrhizal connection established with a species of Nyctangiaceae (Bas 1978), from Atlantic Forest areas in São Paulo State, Southeast Brazil (Grandi et al. 1984, Pegler 1997) and dense ombrophilous forest from Paraná (Meijer 2006 as “A. cf. crebresulcata”). Now, it is reported in the State of Pernambuco, northeastern Brazil, region where the phanerogamic flora is similar to that of the Amazonian Forest (Ducke 1953, Andrade-Lima 1966). Mycorrhizal associations of A. crebresulcata in the case of our collections were not observed, but the basidiomata were found among trees of Annonaceae, Bignoniaceae, Euphorbiaceae, Erythroxilaceae, Fabaceae, Mimosaceae, and other families.

\section{Acknowledgements}

The authors thanks Dr. Rodham E. Tulloss (New Jersey, USA), Dr. Zhu L. Yang (Kunming Institute Botany, Yunnan, China), Ms. C. Vagner G. Cortez (UFRGS, Brazil), Dr. Maria Jesus Nogueira Rodal (UFRPE, Brazil), Dr. Neiva T. Oliveira and Dr. Marilene S. Cavalcanti (UFPE, Brazil) and INPA Herbarium for valuable help during the elaboration of the manuscript; CNPq by providing grants to L.C. Maia (PP-processo 301126/2005-4) and F. Wartchow (DTI-processo 390261/05-0) and for financial support (processo 170067/02-5).

\section{Literature cited}

Andrade-Lima, D. 1966. Contribuição ao paralelismo da flora Amazônico-Nordestina. Boletim Técnico do Instituto de Pesquisas Agronômicas de Pernambuco 19: 1-30.

Bas, C. 1969. Morphology and subdivision of Amanita and a monograph of its section Lepidella. Persoonia 5: 285-579.

Bas, C. 1978. Studies in Amanita I. Some Amazonian species. Persoonia 10: 1-22.

Bas, C. \& Meijer, A.A.R. 1993. Amanita grallipes, a new species in Amanita subsection Vittadiniae from southern Brazil. Persoonia 15: 345-350.

Dennis, R.W.G. 1952. Lepiota and allied genera in Trinidad, British West Indies. Kew Bulletin 7: 459-499.

Drehmel, D., Moncalvo, J.-M. \& Vilgalys, R. 1999. Molecular phylogeny of Amanita based on largesubunit ribosomal DNA sequences: implications for taxonomy and character evolution. Mycologia 91: 610-618. 
Ducke, A. 1953. As leguminosas de Pernambuco e Paraíba. Memórias do Instituto Oswaldo Cruz 5: 417-461.

Giachini, A.J., Oliveira, V.L., Castellano, M.A. \& Trappe, J.M. 2000. Ectomycorrhizal fungi in Eucalyptus and Pinus plantations in Southern Brazil. Mycologia 92: 1166-1177.

Grandi, R.A.P., Guzmán, G. \& Bononi, V.L.R. 1984. Adições às Agaricales (Basidiomycetes) do Parque Estadual das Fontes do Ipiranga, São Paulo, Brasil. Rickia 11:27-33.

Homrich, M.H. 1965. Nota sobre Amanita muscaria (L. ex Fr.) Pers. ex Hooker no planalto Riograndense. Sellowia 17: 77-78.

Maerz, A.J. \& Paul, M.R. 1950. A dictionary of color. 2 ed. McGraw-Hill, New York.

Meijer,A.A.R. 2006. A preliminary list of the Macromycetes from the Brazilian State of Paraná. Boletim do Museu Botânico Municipal 68: 1-55.

Moncalvo, J.-M., Drehmel, D. \& Vilgalys, R. 2000. Variation in modes and rates of evolution in nuclear and mitochondrial ribosomal DNA in the mushroom genus Amanita (Agaricales, Basidiomycota): phylogenetic implications. Molecular Phylogenetic and Evolution 16: 48-63.

Pegler, D.N. 1983. Agaric flora of the Lesser Antilles. Kew Bulletin Additional Series 9: 1-668.

Pegler, D.N. 1997. The agarics of São Paulo, Brazil. Royal Botanical Gardens, London.
Sectma. 2001. Diagnóstico das reservas ecológicas: Região Metropolitana do Recife. Secretaria Estadual de Ciência, Tecnologia e Meio Ambiente do Estado de Pernambuco, Recife.

Sobestiansky, G. 2005. Contribution to a macromycete survey of the States of Rio Grande do Sul and Santa Catarina in Brazil. Brazilian Archives of Biology and Technology 48: 437-457.

Tulloss, R.E. 1993. Amanita pachysperma, Amanita subvirginiana and Amanita virginiana (taxonomy and distribution) with notes in descriptions of the lamella trama in Amanita. Mycotaxon 49: 449-475.

Tulloss, R.E. 1994. Type studies in Amanita section Vaginatae I. Some taxa described in this century (Studies 1-23) with notes on description of spores and refractive hyphae. Mycotaxon 52: 305-396.

Tulloss, R.E., Ovrebo, C.L. \& Halling, R.E. 1992. Studies on Amanita (Agaricales) from Andean Colombia. Memoirs of the New York Botanical Garden 66: 1-46.

Wartchow, F., Tulloss, R.E. \& Cavalcanti, M.A.Q. 2007. The discovery of Amanita lilloi in Brazil. Mycotaxon 99: 167-174.

Weiß, M., Yang, Z.-L. \& Oberwinkler, F. 1998. Molecular phylogenetic studies in the genus Amanita. Canadian Journal of Botany 76: 1170-1179.

Yang, Z.-L. \& Oberwinkler, F. 1999. Die Fruchtköperentwicklung von Amanita muscaria (Basidiomycetes). Nova Hedwigia 68: 441-468. 